\title{
New pyridine-containing non-cyclic and macrocyclic Schiff bases: synthesis and interferon-inducing activity
}

\author{
Regina Lozytska, ${ }^{a}$ Danyla Kryzhanovsky, ${ }^{a}$ Alexander Mazepa, ${ }^{a}$ Viktor Gorodniuk, ${ }^{a}$ \\ Victor Kuz'min, ${ }^{a}$ Viktor Lozitsky, ${ }^{b}$ Alla Fedchuck, ${ }^{b}$ Svitlana Rybalko, ${ }^{c}$ Svitlana Diadiun, ${ }^{c}$ \\ and Jean Jacques Vanden Eynde* ${ }^{d}$ \\ ${ }^{a}$ A.V. Bogatsky Physico-Chemical Institute of the National Academy of Sciences, 86 \\ Lustdorfskaya Doroga, 65080, Odessa, Ukraine \\ ${ }^{b}$ I.I. Mechnikov Ukrainian Research Anti-Plague Institute, 2/4 Ulitsa Tserkovnaya , \\ 65003, Odessa, Ukraine \\ ${ }^{c}$ Lev Gromashevski Institute of Epidemiology and Infectious Diseases, 4 Protasov Yar, \\ 03038, Kiev, Ukraine \\ ${ }^{d}$ Xavier University of Louisiana, College of Pharmacy, Division of Basic Pharmaceutical \\ Sciences, 1 Drexel drive, New Orleans, LA 70125, USA \\ E-mail:jjvde@umh.ac.be
}

Dedicated to our colleague and friend Natalya Dyachenko, in memoriam

(received 11 May 04; accepted 23 Sept 04; published on the web 28 Sept 04)

\begin{abstract}
A series of new Schiff bases containing the Hantzsch pyridine skeleton has been synthesized by reaction of an appropriate aldehyde with 2,6-dimethyl-3,5-pyridinedicarboxhydrazide. The structure of the final products, which was highly dependent on the nature of the starting aldehyde, could readily be ascertained by their spectral data. 2,6- Dimethyl-3,5pyridinedicarboxhydrazide itself and some of its derivatives emerged as potential interferon inducers.
\end{abstract}

Keywords: Interferon inducer, pyridine, Schiff base

\section{Introduction}

As part of our joint research project ${ }^{1,2}$ aimed at the rational design of pyridine-containing macrocycles ${ }^{3-6}$ to afford drugs exhibiting high antiviral potency, we recently focused our attention on derivatives articulated on Hantzsch pyridines, which are known to be the first metabolites ${ }^{7}$ of the corresponding 1,4-dihydropyridines frequently used in the treatment of cardiovascular diseases. ${ }^{8}$ In this paper we wish to report that the 4-unsubstituted 2,6-dimethyl- 
3,5-pyridinedicarboxhydrazide (2) is an excellent precursor for the preparation of a variety of new Schiff bases, including a macrocycle characterized by a 22-membered ring that incorporates four aromatic systems. Interferon-inducing activity of those original compounds was studied in vitro.

\section{Results and Discussion}

In the laboratory Hantzsch pyridines ${ }^{9-13}$ are readily prepared by a two-step sequence (Scheme 1). The first step is a multicomponent reaction effected from an aldehyde, a $\beta$-ketoester, and ammonia that yields a 1,4-dihydropyridine. The so-obtained heterocycle can then be oxidized by a plethora of reagents.

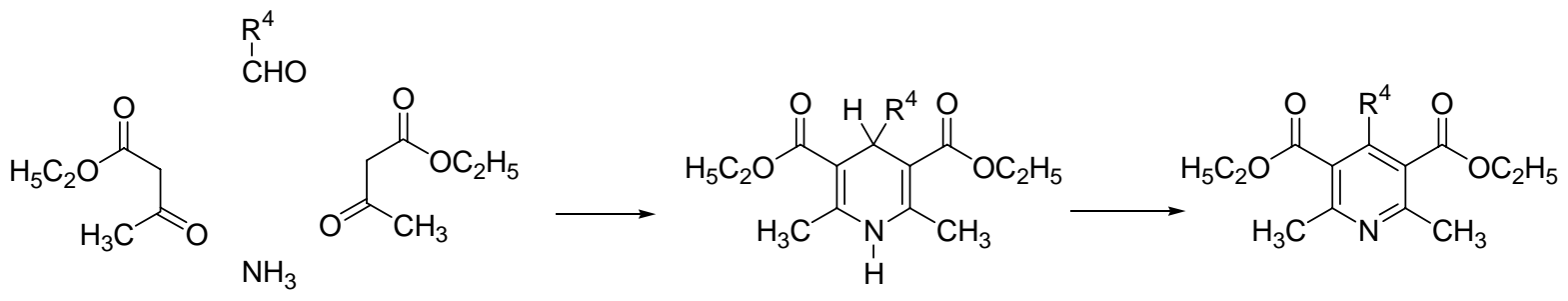

Scheme 1. Two-step synthesis of Hantzsch pyridines.

For the purpose of this work, the parent derivative (1) was converted into the dihydrazide 2 by treatment with hydrazine and the targeted imines (Scheme 2) were obtained by condensation with appropriate aldehydes in ethanol in the presence of acetic acid. Interestingly, we noticed that reaction of 2 with an excess of 2-hydroxy-1-naphthaldehyde, 2,4-dihydroxybenzaldehyde or 4-indolecarboxaldehyde invariably yielded the corresponding monoimines 10-12. That can reasonably be attributed to solubility reasons because those compounds (10-12) precipitated as they formed.

Starting from 2 and 2,6-bis[(2-formylphenyl)oxymethyl]pyridine (13), the macrocycle 14 (Scheme 3) could be isolated in $65 \%$ yield when the experiment was carried out under high dilution conditions, as described earlier. ${ }^{14}$

As expected the final compounds were characterized, in the IR spectra, by an intense carbonyl band between $1620-1660 \mathrm{~cm}^{-1}$ and low absorptions due to the N-H stretching between 3130 and $3400 \mathrm{~cm}^{-1}$. The $\mathrm{C}=\mathrm{N}$ imine double bond gave rise to a peak between 1595 and 1640 $\mathrm{cm}^{-1}$. In addition to those features, the IR spectra of derivatives 3-5, 10, and 11 also exhibited bands attributed to the $\mathrm{O}-\mathrm{H}$ vibration between 3400 and $3600 \mathrm{~cm}^{-1}$. In the ${ }^{1} \mathrm{H}$ NMR spectra, the imine proton could be detected by a signal between 8.00 and $8.20 \mathrm{ppm}$ for all substances.

Under electronic impact, the molecular ions appeared to be fairly unstable as their intensity varied from $0.1 \%$ (for 6) to $40 \%$ (for 3). The most intense peak sometimes resulted from an acyl rupture (derivatives 3 and 8 ) but most often could be attributed to the formation of the $\mathrm{RCN}^{+}$ radical ion as indicated in Table 1. 
Table 1. Mass spectra for compounds 3-12

\begin{tabular}{llllll}
\hline$\#$ & $\mathrm{M}^{+.}$ & {$[\mathrm{M}-\mathrm{RCN}]^{+.}$} & {$[\mathrm{M}-\mathrm{RCHNNH}]^{+}$} & {$[\mathrm{RCN}]^{+}$} & {$\left[\mathrm{RCN}-\mathrm{CH}_{3}\right]^{+.}$} \\
\hline $\mathbf{3}$ & $431(40)$ & $312(20)$ & $296(100)$ & $119(30)$ & - \\
$\mathbf{4}$ & $491(30)$ & $342(40)$ & $326(28)$ & $149(94)$ & $134(100)$ \\
$\mathbf{5}$ & $655(10)$ & $424(4)$ & $408(3)$ & $231(21)$ & $216(100)$ \\
$\mathbf{6}$ & $599(>0.1)$ & $396(1)$ & - & $203(100)$ & - \\
$\mathbf{7}$ & $599(>0.1)$ & $396(2)$ & - & $203(100)$ & - \\
$\mathbf{8}$ & $435(29)$ & $314(11)$ & $298(82)$ & $121(5)$ & $106(25)$ \\
$\mathbf{9}^{\mathbf{a}}$ & - & - & - & - & - \\
$\mathbf{1 0}$ & $377(1)$ & $362(>1)$ & $346(4)$ & $169(100)$ & - \\
$\mathbf{1 1}$ & $343(22)$ & - & $202(12)$ & $135(100)$ & - \\
$\mathbf{1 2}$ & $350(4)$ & $208(2)$ & $192(7)$ & $142(100)$ & - \\
\hline
\end{tabular}

a decomposed by heating; FAB-MS: $[\mathrm{M}+\mathrm{Na}]^{+}$at $\mathrm{m} / \mathrm{z}=802$

Spectroscopic data suggested that all reactions yielded one isomer only but they do not allow to ascertain their spatial configuration. One could however anticipate that the $E$ isomers are the most stable forms. That assumption is well supported by some theoretical calculations ${ }^{15}$ performed on the model compound $N^{3}, N^{5}$-bis(ethylidene)-2,6-dimethyl-3,5-pyridinedicarboxhydrazide as well as on 14. The results of those calculations are reported in Schemes 4 and 5.

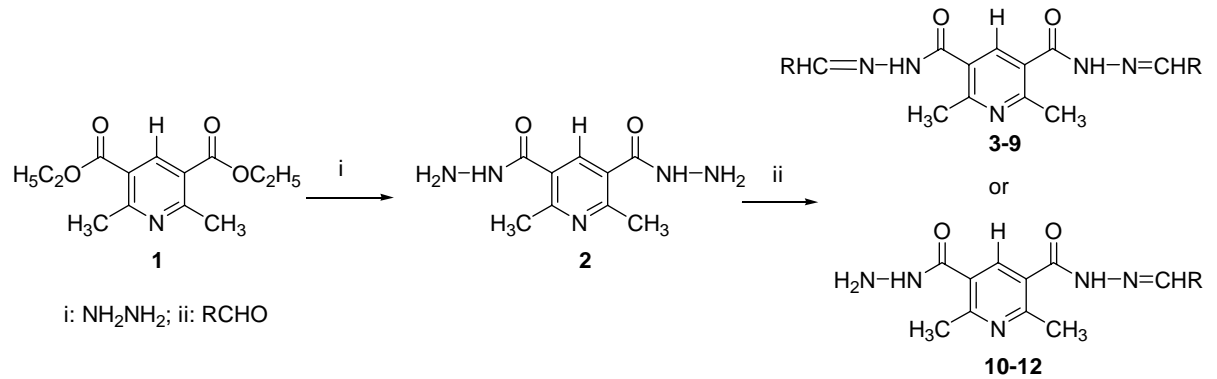

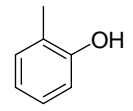

$\mathrm{R}$ in $\mathbf{3}$

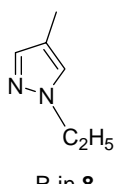

$R$ in 8

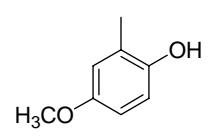

$\mathrm{R}$ in 4
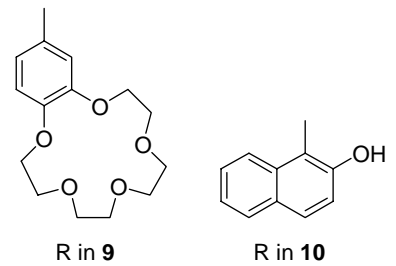

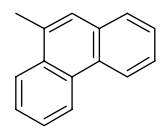

$\mathrm{R}$ in 7

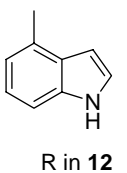

Scheme 2. Structure of compounds 1-12. 

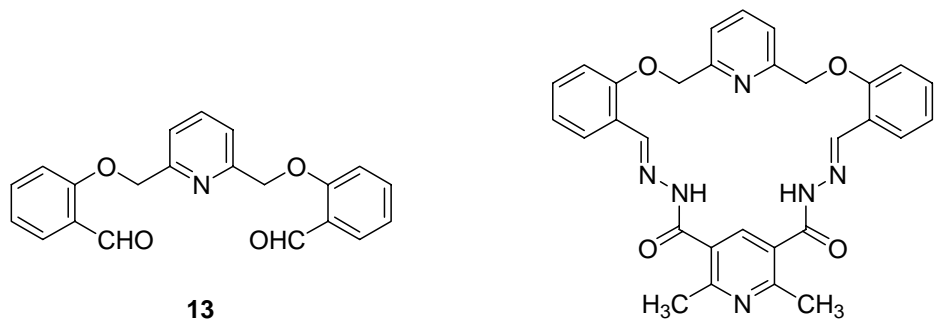

14

Scheme 3. Structure of compounds $\mathbf{1 3}$ and 14.
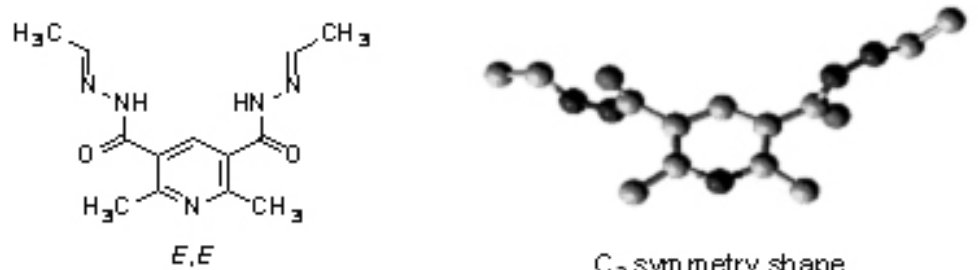

$\mathrm{C}_{2}$ sym metry shape
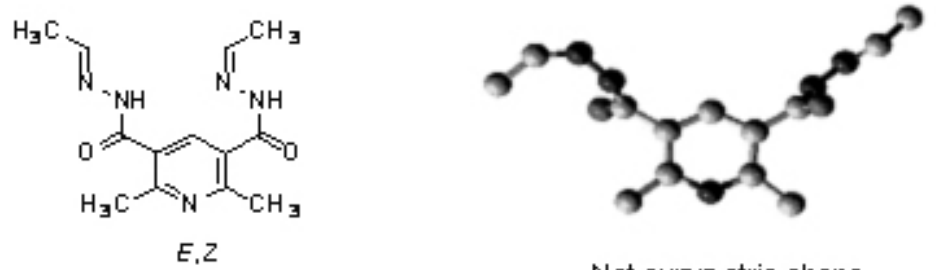

Not symm etric shape
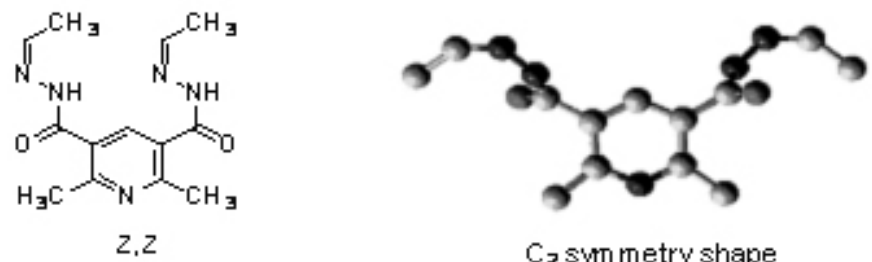

$\mathrm{C}_{2}$ sym metry shape

\begin{tabular}{ccccc}
\hline & $\begin{array}{c}\mathrm{E}(\mathrm{MM})^{\mathrm{a}} \\
\mathrm{Kcal} / \mathrm{mol}\end{array}$ & $\begin{array}{c}\mathrm{E}(\mathrm{MINDO} / 3) \\
\text { Kcal/mol }\end{array}$ & $\begin{array}{c}\mathrm{E}(\mathrm{MNDO}) \\
\text { Kcal/mol }\end{array}$ & $\begin{array}{c}\text { E (PM3) } \\
\text { Kcal/mol }\end{array}$ \\
\hline$E, E$ & 30 & -3870 & -3795 & -3788 \\
$E, Z$ & 38 & -3866 & -3794 & -3786 \\
$Z, Z$ & 42 & -3864 & -3792 & -3787 \\
\hline
\end{tabular}

${ }^{\mathrm{a}}$ Force field $-\mathrm{MM}+$

Scheme 4. Optimized structures of a model compound. 

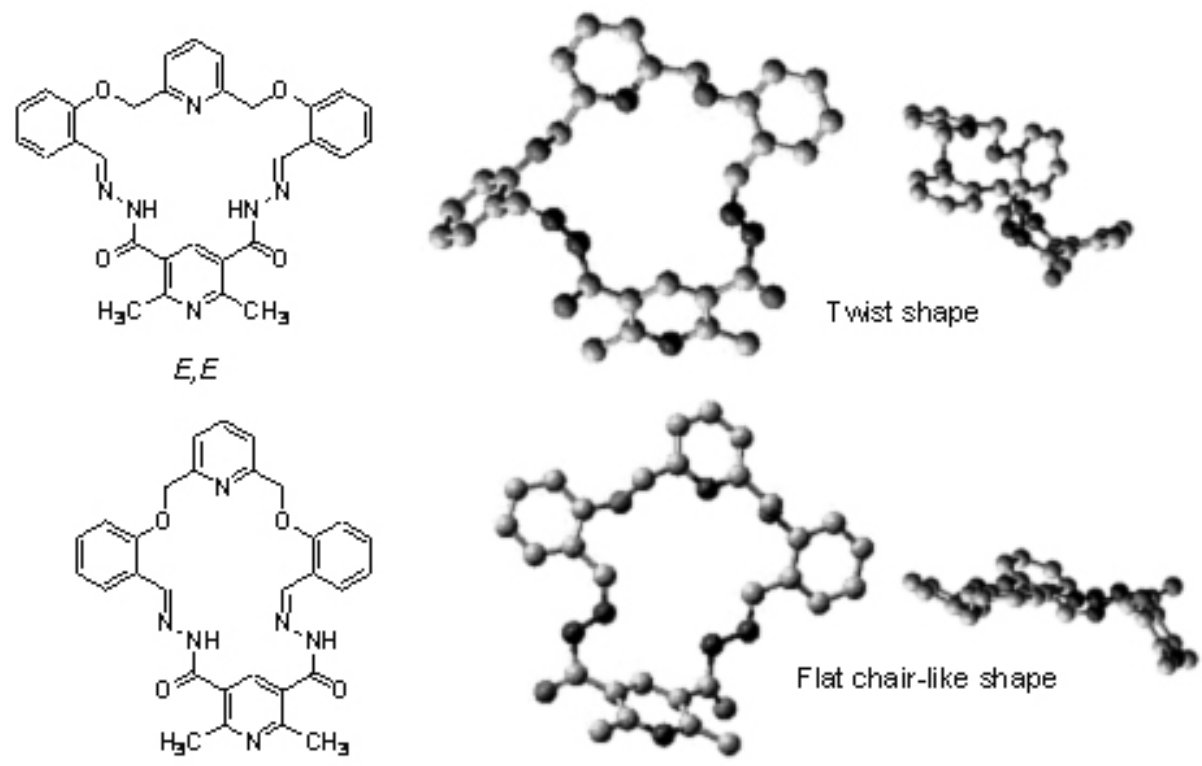

$E, Z$
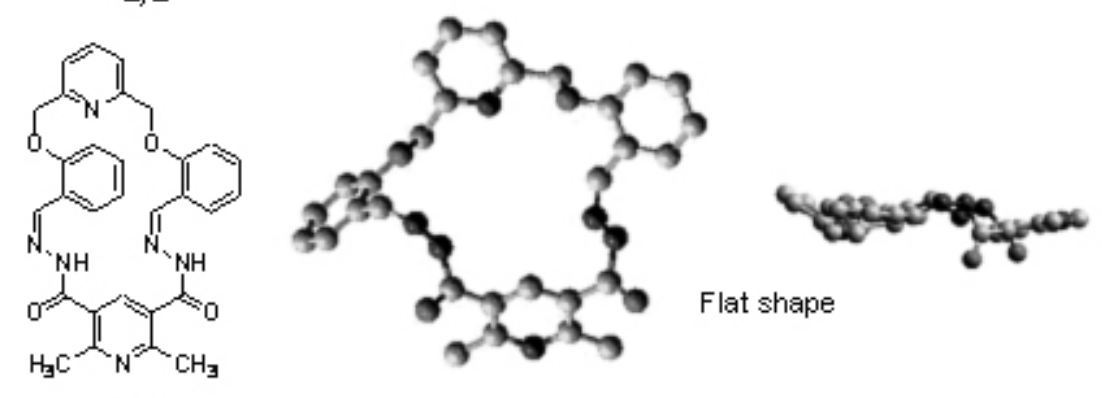

32

\begin{tabular}{ccc}
\hline & $\begin{array}{c}\mathrm{E}(\mathrm{MM})^{\mathrm{a}} \\
\mathrm{Kcal} / \mathrm{mol}\end{array}$ & $\begin{array}{c}\mathrm{E}(\mathrm{PM} 3) \\
\mathrm{Kcal} / \mathrm{mol}\end{array}$ \\
\hline$E, E$ & 35 & -7351 \\
$E, Z$ & 36 & -7351 \\
$Z, Z$ & 43 & -7353 \\
\hline
\end{tabular}

${ }^{\mathrm{a}}$ Force field $-\mathrm{MM}+$

Scheme 5. Optimized structures of 14.

Interferons (IFNs) are the group of immunoregulatory proteins synthesized by $\mathrm{T}$ lymphocytes, fibroblasts, and other types of cells following stimulation with viruses, antigens, mitogens, double-stranded DNA, lectins, or some low molecular compounds. IFNs are classified as alpha and beta, which have antiviral properties, and as gamma which is known as immune IFN. They enhance the ability of macrophages to destroy tumor cells, viruses, and bacteria. IFNs alpha and beta are acid stable and synthesized mainly by leukocytes and fibroblasts. IFN gamma 
is acid labile and is formed mainly by $\mathrm{T}$ lymphocytes stimulated by antigen or mitogen. Whereas the ability of IFNs to prevent infection of noninfected cells is species specific, it is not virus specific. Essentially, all viruses are subject to their inhibitory action. IFNs are not themselves viricidal. They induce formation of a second inhibitory protein that prevents viral messenger RNA translation. That fact has widely encouraged identification and development of agents capable of inducing production of interferon. Among the derivatives we prepared, only the parent compound 2 and the imines 8, 9, 10, and 12 fulfilled the solubility conditions for screening. The interferon-inducing properties of those five substances were determined by using human leukocytes ( 3 millions cells $/ \mathrm{mL}$ ) and levels of produced interferons were subsequently measured by inhibition of vesicular stomatitis virus replication in A549 cells. ${ }^{16,17}$ The results of the study, in which poly(I:C) was used as the reference inducer, are collected in Table 2.

The data indicated that the monoimine 10, bearing a $\beta$-naphthol moiety, was an effective but poor inducer. The parent derivative 2 , the bisimine 9 bearing crown-ethers substituents, and the indole monoimine $\mathbf{1 2}$ were 8-fold more active than 10. Remarkably, substance 8, characterized by the presence of 4-pyrazolyl rings on the nitrogen atoms of the imine groups, was highly active and could compete with poly(I:C). All studied compounds induced acid stable interferon that is classified as alpha interferon.

Mention should be made that compound 2, at a dose of $100 \mu \mathrm{M}$, exhibited also an antiherpetic effect on type 1 herpes simplex virus (HSV) strain US using the cytomorphological method. ${ }^{18}$ Indeed it decreased the number of infected cells to $52 \%$ (Control=100\%). A detailed morphological study of the infected cells had shown that intranuclear virus-specific inclusion bodies formed in presence of $\mathbf{2}$ were optically more friable and transparent then inclusion bodies formed in the absence 2 . These changes indicate failure of virus replication cycle and defective viral particles forming under action of $\mathbf{2}$.

Anti-influenza activity of 2 against influenza virus strain A/Hong-Kong/1/68(H3N2) was also measured using the method of inhibition of viral replication in chorioallantoic membranes of chicken embryos. ${ }^{19}$ However $\mathbf{2}$ appeared to be devoid of effect.

\section{Conclusions}

We found that Schiff bases derived from 2,6-dimethyl-3,5-pyridinedicarboxhydrazide could readily be synthesized. Despite their poor solubility, some of those Schiff bases constituted promising interferon inducers. In particular, compound $\mathbf{8}$ emerged as an interesting lead that was only two-fold less active than Poly I:C. 
Table 2. Interferon-inducing activities of selected compounds

\begin{tabular}{cccc}
\hline \multirow{2}{*}{$\#$} & \multicolumn{2}{c}{ Level of interferon induction (I.U./mL) } \\
\cline { 2 - 3 } & & $\mathrm{pH} \mathrm{7.3}$ & PH 2.0 \\
\hline $\mathbf{8}$ & 320 & 320 \\
$\mathbf{9}$ & 1280 & 1280 \\
$\mathbf{1 0}$ & 320 & 320 \\
$\mathbf{1 2}$ & 40 & 40 \\
Poly I:C & 320 & 320 \\
\hline
\end{tabular}

\section{Experimental Section}

General Procedures. Starting reagents and solvents were obtained from Aldrich or Acros. IR spectra were obtained on a Specord M-80 spectrophotometer. ${ }^{1} \mathrm{H}$ NMR spectra were recorded on a Bruker WM-300 (300 MHz) spectrometer using tetramethylsilane as an internal reference; chemical shifts are given in ppm. Mass spectra were recorded with a Varian MAT-112 mass spectrometer using the direct inlet system with ionization energy of $70 \mathrm{eV}$, an emission current of $100 \mu \mathrm{A}$, and ion source temperature of $220^{\circ} \mathrm{C}$. FAB-MS were recorded on a VG 7070EQ mass spectrometer using an Argon atoms beam of $10 \mathrm{KV}$. The elemental analyses were carried out at the microanalysis laboratory of the Physico-Chemical Institute of NAS, Odessa, Ukraine.

2,6-Dimethyl-3,5-pyridinedicarboxhydrazide (2) ${ }^{20}$ and 2,6-bis(formylaryloxymethyl)pyridine (13) ${ }^{21}$ were prepared according to described procedures.

\section{General procedure for the preparation of compounds 3 - 12}

A solution of 2,6-dimethyl-3.5-pyridinedicarboxhydrazide $(0.223 \mathrm{~g} ; 1 \mathrm{mmol})$ in ethanol $(30 \mathrm{~mL})$ was added to solution of aldehyde $(4 \mathrm{mmol})$ and acetic acid $(1 \mathrm{~mL})$ in ethanol $(50 \mathrm{~mL})$ under stirring. After a reaction period (TLC) ranging from 0.5 to $5.0 \mathrm{~h}$ depending on the nature of the aldehyde, the precipitate was filtered and washed with ethanol. Recrystallization from a mixture (1:5) of chloroform and hexane afforded a pure analytical sample.

$N^{\prime 3}, N^{\mathbf{5}}$-Bis[(2-hydroxyphenyl)methylidene]-2,6-dimethyl-3,5-pyridinedicarboxhydrazide (3). Yield: $60 \%$. Mp. $340{ }^{\circ} \mathrm{C}$ (decomp). IR (KBr), $\mathrm{cm}^{-1}: 3500(\mathrm{OH}), 3170(\mathrm{NH}), 1630(\mathrm{C}=\mathrm{O})$, $1600(\mathrm{C}=\mathrm{N}) .{ }^{1} \mathrm{H}$ NMR: $\delta 2.60\left(6 \mathrm{H}, \mathrm{s}, \mathrm{CH}_{3}\right), 6.80-7.60(8 \mathrm{H}, \mathrm{m}, \mathrm{Ar}), 7.90(1 \mathrm{H}, \mathrm{s}, \mathrm{Pyr}), 8.10(2 \mathrm{H}, \mathrm{s}$ $\mathrm{CH}=\mathrm{N}), 11.05(2 \mathrm{H}, \mathrm{s}, \mathrm{OH}), 12.10(2 \mathrm{H}, \mathrm{s} \mathrm{NH})$. Anal. Calcd. for $\mathrm{C}_{23} \mathrm{H}_{21} \mathrm{~N}_{5} \mathrm{O}_{4}: \mathrm{C}, 64.03 ; \mathrm{H}, 4.91$; N, 16.23. Found: C, 64.21; H, 4.87; N, 16.19.

$N^{\prime 3}, N^{\prime 5}$-Bis[(2-hydroxy-5-methoxyphenyl)methylidene]-2,6-dimethyl-3,5-

pyridinedicarboxhydrazide (4). Yield: 80\%. Mp. $318^{\circ} \mathrm{C}$. IR (KBr), $\mathrm{cm}^{-1}: 3500(\mathrm{OH}), 3180$ $(\mathrm{NH}), 2820,1650(\mathrm{C}=\mathrm{O}), 1630(\mathrm{C}=\mathrm{N}) .{ }^{1} \mathrm{H}$ NMR: the compound could not be dissolved. Anal. Calcd. for $\mathrm{C}_{25} \mathrm{H}_{25} \mathrm{~N}_{5} \mathrm{O}_{6}$ : C, 61.09; H, 5.13; N, 14.25. Found: C, 61.19; H, 5.07; N, 14.28. 


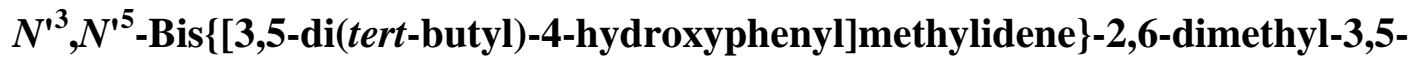

pyridinedicarboxhydrazide (5). Yield: $55 \%$. Mp. $380{ }^{\circ} \mathrm{C}$ (decomp). IR (KBr), $\mathrm{cm}^{-1}: 3610(\mathrm{OH})$, $3180(\mathrm{NH}), 1660(\mathrm{C}=\mathrm{O}), 1640(\mathrm{C}=\mathrm{N}) .{ }^{1} \mathrm{H}$ NMR: $\delta 1.41(36 \mathrm{H}, \mathrm{s}, \mathrm{t}-\mathrm{But}), 2.59(6 \mathrm{H}, \mathrm{s}, \mathrm{Me}-\mathrm{Pyr})$, 7.00-8.00 (5H, s, Ar), $8.15(2 \mathrm{H}, \mathrm{s} \mathrm{CH}=\mathrm{N}), 11.60(2 \mathrm{H}, \mathrm{s}, \mathrm{OH}), 11.10(2 \mathrm{H}, \mathrm{s} \mathrm{NH})$. Anal. Calcd. for $\mathrm{C}_{39} \mathrm{H}_{53} \mathrm{~N}_{5} \mathrm{O}_{4}$ : C, 71.42; H, 8.15; N, 10.68. Found: C, 71.40; H, 8.19; N, 10.57.

2,6-Dimethyl- $N^{\prime 3}, N^{\prime 5}$-bis(9-anthracenylmethylidene)-3,5-pyridinedicarboxyhydrazide (6). Yield: 45\%. Mp. $360{ }^{\circ} \mathrm{C}$ (sublim). IR (KBr), $\mathrm{cm}^{-1}$ : $3160(\mathrm{NH}), 1650(\mathrm{C}=\mathrm{O}), 1620(\mathrm{C}=\mathrm{N}) .{ }^{1} \mathrm{H}$ NMR: the compound could not be dissolved. Anal. Calcd. for $\mathrm{C}_{39} \mathrm{H}_{29} \mathrm{~N}_{5} \mathrm{O}_{2}: \mathrm{C}, 78.11 ; \mathrm{H}, 4.87 ; \mathrm{N}$, 11.68. Found: C, 78.19; H, 4.79; N, 11.67.

2,6-Dimethyl- $N^{\mathbf{3}}, \boldsymbol{N}^{\mathbf{5}}$-bis[9-phenanthrylmethylidene]-3,5-pyridinedicarboxhydrazide (7).

Yield: 90\%. Mp. $315{ }^{\circ} \mathrm{C}$ (decomp). IR (KBr), $\mathrm{cm}^{-1}$ : $3140(\mathrm{NH}), 1630(\mathrm{C}=\mathrm{O}), 1620(\mathrm{C}=\mathrm{N}) .{ }^{1} \mathrm{H}$ NMR: $\delta 2.70(6 \mathrm{H}, \mathrm{s}, \mathrm{Me}-\mathrm{Pyr}), 7.40-7.90(18 \mathrm{H}, \mathrm{m}, \mathrm{Ar}), 8.00(1 \mathrm{H}, \mathrm{s}, \mathrm{Pyr}), 8.10(2 \mathrm{H}, \mathrm{s} \mathrm{CH}=\mathrm{N})$, 11.85 (2H, s, NH). Anal. Calcd. For $\mathrm{C}_{39} \mathrm{H}_{29} \mathrm{~N}_{5} \mathrm{O}_{2}$ : C, 78.11; H, 4.87; N, 11.68. Found: C, 78.15; $\mathrm{H}, 4.84 ; \mathrm{N}, 11.66$.

$N^{\prime 3}, N^{\prime 5}$-Bis[(1-ethyl-1H-pyrazol-4-yl)methylidene]-2,6-dimethyl-3,5-

pyridinedicarboxhydrazide (8). Yield: $85 \%$. Mp. $287^{\circ} \mathrm{C}$ (decomp). IR (KBr), $\mathrm{cm}^{-1}: 3130(\mathrm{NH})$, $1650(\mathrm{C}=\mathrm{O}), 1630(\mathrm{C}=\mathrm{N}) .{ }^{1} \mathrm{H}$ NMR: $\delta 1.40(6 \mathrm{H}, \mathrm{t}, \mathrm{Me}), 2.60(6 \mathrm{H}, \mathrm{s}, \mathrm{Me}-\mathrm{Pyr}), 4.15\left(4 \mathrm{H}, \mathrm{q}, \mathrm{CH}_{2}\right)$, 7.50-7.90 (4H, s, pyraz), $8.00(1 \mathrm{H}, \mathrm{s}, \mathrm{Pyr}), 8.20(2 \mathrm{H}, \mathrm{s}, \mathrm{CH}=\mathrm{N}), 11.65(2 \mathrm{H}, \mathrm{s}, \mathrm{NH})$. Anal. Calcd. For $\mathrm{C}_{21} \mathrm{H}_{25} \mathrm{~N}_{9} \mathrm{O}_{2}$ : C, 57.92; H, 5.79; N, 28.95. Found: C, 57.93; H, 5.80; N, 28.92.

2,6-Dimethyl- $N^{\prime 3}, N^{\prime 5}$-bis[2,3,5,6,8,9,11,12-octahydro-1,4,7,10,13-

benzopentaoxacyclopentadecan-15-ylmethylidene]-3,5-pyridinedicarboxhydrazide (9). Yield: $80 \%$. Mp. $322{ }^{\circ} \mathrm{C}$ (decomp). IR (KBr), $\mathrm{cm}^{-1}: 3140(\mathrm{NH}), 2980,2800,1620(\mathrm{C}=\mathrm{O}), 1595(\mathrm{C}=\mathrm{N})$. ${ }^{1} \mathrm{H}$ NMR: $\delta 2.65$ (6H, s, Me-Pyr), 3.50-4.20 (32H, m, $\left.\mathrm{CH}_{2}\right), 6.90-7.40(6 \mathrm{H}, \mathrm{m}, \mathrm{Ar}), 8.00(1 \mathrm{H}, \mathrm{s}$, Pyr), $8.20(2 \mathrm{H}, \mathrm{s}, \mathrm{CH}=\mathrm{N}), 11.80(2 \mathrm{H}, \mathrm{s}, \mathrm{NH})$. Anal. Calcd. For $\mathrm{C}_{39} \mathrm{H}_{49} \mathrm{~N}_{5} \mathrm{O}_{12}$ : C, 60.07; H, 6.33; $\mathrm{N}, 8.98$. Found: C, 60.05; H, 6.37; N, 8.95.

$N^{3}$-[(2-Hydroxy-1-naphthyl)methylidene]-2,6-dimethyl-3,5-pyridinedicarboxhydrazide (10). Yield: $50 \%$. Mp. $337^{\circ} \mathrm{C}$. IR ( $\left.\mathrm{KBr}\right), \mathrm{cm}^{-1}$ : $3400(\mathrm{OH}), 3160(\mathrm{NH}), 1650(\mathrm{C}=\mathrm{O}), 1630(\mathrm{C}=\mathrm{N})$. ${ }^{1} \mathrm{H}$ NMR: $\delta .270\left(6 \mathrm{H}, \mathrm{s}, \mathrm{CH}_{3}\right), 7.15-8.30(7 \mathrm{H}, \mathrm{m}, \mathrm{Ar}), 8.10(1 \mathrm{H}, \mathrm{s}, \mathrm{CH}=\mathrm{N}), 9.30\left(1 \mathrm{H}, \mathrm{s}, \mathrm{NH}-\left[\mathrm{NH}_{2}\right]\right), 10.70$ $\left(2 \mathrm{H}, \mathrm{s}, \mathrm{NH}_{2}\right), 12.20(1 \mathrm{H}, \mathrm{s}, \mathrm{NH}-[\mathrm{N}=\mathrm{CH}]), 12.50(1 \mathrm{H}, \mathrm{s}, \mathrm{OH})$. Anal. Calcd. for $\mathrm{C}_{20} \mathrm{H}_{19} \mathrm{~N}_{5} \mathrm{O}_{3}$ : C, 63.66; H, 5.07; N, 18.56. Found: C, 63.90; H, 5.17; N, 18.33.

$\boldsymbol{N}^{\mathbf{3}}$-[(2,4-Dihydroxyphenyl)methylidene]-2,6-dimethyl-3,5-pyridinedicarboxhydrazide (11). Yield: 40\%. Mp. $370{ }^{\circ} \mathrm{C}$ (decomp). IR (KBr), $\mathrm{cm}^{-1}: 3600(\mathrm{OH}), 3160(\mathrm{NH}), 1650(\mathrm{C}=\mathrm{O}), 1630$ $(\mathrm{C}=\mathrm{N}) .{ }^{1} \mathrm{H}$ NMR: $\delta 2.60$ (6H, s, Me-Pyr), 6.30-7.80 (3H, m, Ar), 8.00 (1H, s, Pyr), 8.20 (1H, s, $\mathrm{CH}=\mathrm{N}), 8.40(1 \mathrm{H}, \mathrm{s}, \mathrm{NH}), 10.00\left(2 \mathrm{H}, \mathrm{s}, \mathrm{NH}_{2}\right), 11.25(2 \mathrm{H}, \mathrm{s}, \mathrm{OH}), 11.90$ (1H, s, NH). Anal. Calcd. for $\mathrm{C}_{16} \mathrm{H}_{17} \mathrm{~N}_{5} \mathrm{O}_{4}$ : C, 55.97; H, 4.99; N, 20.40. Found: C, 56.11; H, 4.96; N, 20.42.

$\boldsymbol{N}^{\mathbf{3}}$-[1H-Indol-4-ylmethylidene]-2,6-dimethyl-3,5-pyridinedicarboxhydrazide (12). Yield: 55\%. Mp. $307^{\circ} \mathrm{C}$. IR (KBr), $\mathrm{cm}^{-1}: 3400,3180(\mathrm{NH}), 1660(\mathrm{C}=\mathrm{O}), 1630(\mathrm{C}=\mathrm{N}) .{ }^{1} \mathrm{H}$ NMR: $\delta 2.65$ $(6 \mathrm{H}, \mathrm{s}, \mathrm{Me}-\mathrm{Pyr}), 6.90$ (1H, s, NH indol), 7.00-8.30 (6H, m, Ar), 8.00 (1H, s, Pyr), 8.20 (1H, s, $\mathrm{CH}=\mathrm{N}), 8.50(1 \mathrm{H}, \mathrm{s}, \mathrm{NH}), 10.25\left(2 \mathrm{H}, \mathrm{s}, \mathrm{NH}_{2}\right), 11.60(1 \mathrm{H}, \mathrm{s}, \mathrm{NH})$. Anal. Calcd. for $\mathrm{C}_{18} \mathrm{H}_{18} \mathrm{~N}_{6} \mathrm{O}_{2}$ : C, 61.70; H, 5.18; N, 23.99. Found: C, 61.72; H, 5.16; N, 23.97. 
Preparation of macrocycle 15,17,32,34-tetramethyl-3,29-dioxa-11,12,16,20,21,35hexaazapentacyclo[29.3.1.1 $\left.{ }^{14,18} \cdot 0^{4,9} \cdot 0^{23,28}\right]$ hexatriaconta-

1(35),4,6,8,10,14(36),15,17,21,23,25,27,31,33-tetradecaene-13,19-dione $\quad$ (14). 2,6-Bis(2formylphenoxymethyl)pyridine $(\mathbf{1 3}, 0.347 \mathrm{~g} ; \quad 1 \mathrm{mmol})$ and 2,6-dimethyl-3,5pyridinedicarboxhydrazide $(2,0.279 \mathrm{~g} ; 1.25 \mathrm{mmol})$ were separately dissolved in ethanol (50 $\mathrm{mL})$. Both solutions were slowly added to a boiling mixture of ethanol $(300 \mathrm{~mL})$ and acetic acid $(1 \mathrm{~mL})$ over a period of $2 \mathrm{~h}$. After a further heating period of $3 \mathrm{~h}$, the solution was cooled down to the room temperature and the precipitate was filtered and recrystallized from a mixture $(1: 5)$ of DMF and water. Yield: $65 \%$. Mp. $340{ }^{\circ} \mathrm{C}$ (decomp). IR (KBr), $\mathrm{cm}^{-1}: 3150(\mathrm{NH}), 1680(\mathrm{C}=\mathrm{O})$, $1640(\mathrm{C}=\mathrm{N}) .{ }^{1} \mathrm{H}$ NMR: $\delta 2.60\left(6 \mathrm{H}, \mathrm{s}, \mathrm{CH}_{3}\right), 5.25\left(4 \mathrm{H}, \mathrm{s}, \mathrm{CH}_{2} \mathrm{O}\right), 6.90-8.00(12 \mathrm{H}, \mathrm{m}$, arom $), 8.10$ $(2 \mathrm{H}, \mathrm{s}, \mathrm{CH}=\mathrm{N}), 11.90(2 \mathrm{H}, \mathrm{s}, \mathrm{NH})$. Anal. Calcd. for $\mathrm{C}_{30} \mathrm{H}_{26} \mathrm{~N}_{6} \mathrm{O}_{4}: \mathrm{C}, 67.41 ; \mathrm{H}, 4.90 ; \mathrm{N}, 15.72$. Found: C, 68.03; H, 4.95; N, 15.77.

\section{Determination of the interferon-inducing activity ${ }^{16,17}$}

Human leukocytes ( 3 millions cells $/ \mathrm{mL}$ ) were used to study the interferon-inducing properties. The compounds were dissolved in a $3 \%$ solution of DMSO at a concentration of $1 \mathrm{mg} / \mathrm{mL}$, then $100 \mu \mathrm{L}$ of solution were added to the leukocytes suspension. The mixtures were incubated during 18-24 hours at $37^{\circ} \mathrm{C}$ and the interferon titers in supernatants were determined by using the inhibition by interferon of the vesicular stomatitis virus replication in A549 cells.

\section{Determination of the antiherpetic activity ${ }^{18}$}

Hep-2 cells were grown in tubes with strips of cover glasses for 48 hours. Subsequently, the cells were infected with HSV and incubated for $1 \mathrm{~h}$ at room temperature. The unabsorbed virus was removed by washing with Hanks Balanced Salt Solution (HBSS) and the studied substances, dissolved in the maintenance medium (Eagle medium without serum), were added at appropriate concentrations. The infected not treated with the assayed substances cells were used as positive controls of virus infection. The cells were incubated for $48 \mathrm{~h}$ at $37{ }^{\circ} \mathrm{C}$. Then, the infected cells grown on the strips of cover glasses were fixed with $96 \%$ ethanol, washed with HBSS, and stained with $0.01 \%$ acridine orange solution. The number of infected cells with DNA-containing inclusion bodies was counted using a fluorescence microscope.

\section{Determination of the anti-influenza activity ${ }^{19}$}

Anti-influenza activity, at the $\mathrm{mM}$ level, was studied for influenza virus strain A/HongKong/1/68(H3N2). The method of inhibition of viral replication in chorioallantoic membranes (CAM) of 12-14 days age chicken embryos was used. CAM were infected with 1000 TID $_{50}(50 \%$ tissue infected dose) of influenza virus. After incubation during 24 hours at $37^{\circ} \mathrm{C}$, viral infective titers were tested in control and experimental samples. 


\section{Acknowledgments}

The authors are highly grateful to the INTAS Foundation for a financial support (Grant INTAS 97-31528).

\section{References}

1. Kuz'min, V.E.; Lozitsky, V.P.; Kamalov, G.L.; Lozitskaya, R.N.; Zheltvay, A.I.; Fedtchouk, A.S.; Kryzhanovsky, D.N.; Kovdienko, N.A.; Vanden Eynde, J.J.; Dyachenko, N.S.; Nosach, L.N. Exper. Oncology 2000, 22 Supp. 2, 16.

2. Kuz'min V.E.; Artemenko, A.G.; Lozitsky, V.P.; Muratov, E.N.; Fedtchouk, A.S.; Dyachenko, N.S.; Nosach, L.N.; Gridina, T.L.; Shitikova, L.I.; Mudrik, L.M.; Chelombitko, V.A.; Zheltvay, A.I.; Vanden Eynde, J.J. Acta Biochim. Pol. 2002, 49, 157.

3. Newkome, G.R.; Sauer, J.D.; Roper, J.M.; Hager, D.C. Chem. Rev. 1977, 77, 513.

4. Bridger, G.J.; Skelj, R.T.; Thornton, D.; Padmanabhan, S.; Martellucci, S.A.; Henson, G.W.; Abrams, M.J.; Yamamoto, N.; De Vreese, K.; Pauwels, R. J. Med. Chem. 1995. 38, 366.

5. Plenio, H. Angew. Chem., Int. Ed. 1997, 36, 348.

6. An, H.; Cummins, L.L.; Griffey, R.H.; Bharadwaj, R.; Haly, B.D.; Fraser, A.S.; WilsonLingardo, L.; Risen, L.M.; Wyatt, J.R.; Cook, P. D. J. Am. Chem. Soc. 1997, 119, 3696.

7. Bocker, R.H.; Guengerich, F.P. J. Med. Chem. 1986, 29, 1596.

8. Bossert, F.; Meyer, H.; Wehinger, E. Angew. Chem., Int. Ed. 1981, 20, 762.

9. Eisner, U.; Kuthan, J. Chem. Rev. 1972, 72, 1.

10. Maquestiau, A.; Mayence, A.; Vanden Eynde, J.J. Tetrahedron Lett. 1991, 32, 3839.

11. Vanden Eynde, J.J.; Mayence, A.; Maquestiau, A. Tetrahedron 1992, 48, 463.

12. Vanden Eynde, J.J.; Delfosse, F.; Mayence, A.; Van Haverbeke, Y. Tetrahedron 1995, 51, 6511.

13. Vanden Eynde, J.J.; Mayence, A. Molecules 2003, 8, 381.

14. Kamalov, G.; Zakolodiazhnaia, O.; Manolova, A.; Lozitskaya R. Z. Org. Khim. 1992, 62, 687.

15. Calculations by Hyperchem 7.5 software. Hypercube, Inc., $1115 \mathrm{NW} 4^{\text {th }}$ Street, Gainesville, F1 32601 USA. Trial version from http://www.hypercube.com

16. Ho, M.; Enders, J. Proc. Natl. Acad. Sc. 1959, 45, 385.

17. Rybalko, S.; Nesterova, N.; Diadiun, S.; Danilenko, G.; Danilenko, V.; Guzhova, S.; Maksimov, Yu.; Arkadiev, V.; Ivans'ka, N.; Maksymenok, O.; Vrnycianu, N.; Zhtrebtsova, E.; Grigoreva, T. Acta Biochim. Pol. 2001, 48, 241.

18. Alexeeva, I.; Palchikovskaya, L.; Shalamay, A.; Nosach, L.; Zhovnovataya, V.; Povnitsa, O.; Dyachenko, N. Acta Biochim. Pol. 2000, 47, 95.

19. Lozitsky, V.; Puzis, L.; Polyak, R. Acta Virol. 1988, 32, 117.

20. Fox, H.H.; Gibas, J.T. J. Org. Chem. 1952, 17, 1653.

21. Vogtle, F.; Muller, W. Angew. Chem. 1974, 89, 564. 